\title{
ANALISIS POTENSI EKONOMI DESA DAN PROSPEK PENGEMBANGANNYA
}

\author{
Arif Andri Wibowo ${ }^{1}$, dan Muhammad Farid Alfarisy ${ }^{1 *}$ \\ ${ }^{1} J u r u s a n$ IImu Ekonomi dan Studi Pembangunan, Fakultas Ekonomi dan Bisnis, Univesitas \\ Jenderal Soedirman, Indonesia \\ *Email corresponding author: muhammad.farid.alfarisy@unsoed.ac.id
}

\begin{abstract}
Abstrak
Desa mandiri dan berdaya saing merupakan isu yang penting dan menjadi perhatian dari semua elemen masyarakat. Guna mewujudkan desa yang mandiri dan berdaya saing maka pemerintah perlu mengkaji dan memetakan potensi ekonomi desa sebagai sumber daya lokal. Penelitian ini bertujuan untuk mengidentifikasi potensi ekonomi dari sektor pertanian, perkebunan, peternakan, pariwisata, dan industri rumah tangga dan kecil. Penelitian ini adalah penelitian deskriptif dengan menggunakan analisis data primer melalui wawancara dengan semua kepala desa dan sekunder digunakan untuk melengkapi informasi dari sumber data primer. Guna memumnculkan daya saing desa, Pemetaan potensi local perlu mengenali dan menggali potensi dapat dilakukan oleh masyarakat itu sendiri sehingga akan tepat dalam pengembangan desa karena desa sebagai pemerintahan (Kepala dan dan masyarakat) yang memahami dengan jelas potensi baik sumberdaya aam maupun sumber daya manusia yang tersedia. Hasil penelitian menunjukkan komoditas sektor perkebunan merupakan komoditas utama yang dihasilkan, sementara dari sektor peternakan masih memberi dukungan terhadap ternak baik untuk ruminansia dan non-ruminansia. Untuk sektor pariwisata, hanya memilki satu destinasi wisata yang dikelola oleh pemerintah dan dilengkapi dengan fasilitas penunjangnya seperti hotel dan losmen. Sementara untuk sektor industri kecil dan rumah tangga, didominasi oleh industri skala rumah tangga dengan sebagian besar komoditasnya adalah bahan olahan makanan serta gula semut.
\end{abstract}

Kata Kunci: Desa, Pembangunan pedesaan; Potensi ekonomi desa.

\begin{abstract}
An independent and competitive village is an important issue and a concern of all communities. In order to create an independent and competitive village, the government needs to study and map the economic potential of the village as a local resource. This study aims to identify the economic potential of agriculture, plantation, livestock, and tourism sectors. This study is considered as a descriptive study and use both primary and secondary data as source of analysis. Primary data was obtained by interview with all the head of the village, while the secondary data is used to complete the analysis. In order to generate village competitiveness, local potential mapping needs to recognize and explore potentials by the community itself, so that it will be appropriate in village development because the village as a government (head and community) clearly understands the potential of both natural resources and available human resources. The result of our study shows plantation are the main commodities produced in the district. As for livestock, the district still provides support for both ruminants and non-ruminants. In the tourism sector, the district only has one tourism destination that is managed by government and equipped with supporting facilities such as hotels or inn. For small industry, the district is abundant with home-scale industries that produce manufactured food and coconut sugar
\end{abstract}

Keywords: Rural Development, Rural Economic Potential Sectors, Village. 
Jurnal Ekonomi, Bisnis dan Akuntansi (JEBA) Volume 22 No 2 Tahun 2020 


\section{PENDAHULUAN}

Salah satu tujuan pembangunan pedesaaan adalah meningkatkan kesejahteraan masyarakat desa. Rendahnya tingkat kesejahteraan masyarakat di pedesaan masih menjadi salah satu permasalahan pembangunan ekonomi di Indonesia. Data Badan Pusat Statistik (BPS) menunjukkan pada bulan September 2017 ada 16,31 juta masyarakat desa di Indonesia hidup di bawah garis kemiskinan. Lebih lanjut, 23\% rumah tangga kategori pra-sejahtera bekerja di sektor pertanian.

Peningkatan kesejahteraan masyarakat desa sejalan dengan satu dari tujuh belas kesepakatan bersama dalam Sustainable Development Goals (SDGs) pada tahun 2015, yaitu menghapus kemiskinan dalam segala bentuk dimanapun. Tujuan tersebut tertuang menjadi beberapa target, salah satunya adalah menurunkan masyarakat kategori miskin menurut standar nasional menjadi separuhnya. Dengan potret sebagian besar masyarakat miskin di Indonesia berada di wilayah pedesaan, maka program peningkatan kesejahteraan masyarakat desa diharapkan dapat membantu mencapai target yang tertuang dalam SDGs.

Paradigma pembangunan ekonomi menjadi dasar menyelesaikan salah satu masalah pembangunan berupa kemiskinan. Perkembangan paradigma pembangunan mengalami perubahan seiring berjalannya waktu. Program penanggulangan kemisikinan pada era 1950/1960an banyak menekankan pada pembangunan infrasturktur untuk tujuan industrialisasi, dan pembangunan pengairan/irigasi untuk mendukung sektor pertanian. Di era tahun 1980an pasca perang dunia kedua, pembangunan ekonomi dilakukan melalui pembangunan yang terencana. Bahkan Todaro dan Smith (2012) menyebut perencanaan pembangunan sebagai the surest and direct route to economic growth. Sementara di tahun 1990an pembangunan mulai melihat pada partisipasi aktif masyarakat sebagai subjek dan objek dari pembangunan itu sendiri. Jikalau meminjam istilah dari Chambers (1994), paradigma pembangunan saat ini telah mengalami perubahan dari pembangunan yang sifatnya things menjadi pembangunan yang sifatnya people atau dari pembangunan berorientasi fisik menjadi pembangunan yang beroerinteasi kepada manusia.

Program pembangunan pedesaan bertujuan pada pada peningkatan kesejahteraan masyarkat. Seringkali kesejahteraan masayarakat hanya dikaitkan dengan kekayaan atau akumulasi kekayaan dan kepemilikan harta benda. Sehingga kesejahteraan hanya dainggap sebagai kemampuan untuk melakukan konsumsi (Kasser et al. 2007). Pembangunan pedesaan di masa lampau menurut Rivera, et al. (2017) hanya berhubungan dengan masalah bagaimana melakukan modernisasi di sektor pertanian dan mengambil manfaat ekonomi langsung yang dihasilkan dari modernisasi tersebut.

Seiring dengan perkembangan masyarakat yang semakin kompleks, maka untuk menyelesaikan masalah pembangunan dibutuhkan pendekatan dari berbagai multidisiplin. Pouw dan Gupta (2017) menyebut program pembangunan multi disiplin ini sebagai pembangunan inklusif. Pembangunan inklusif tidak hanya melihat pada satu aspek ekonomi saja, tapi juga melihat aspek sosial seperti keterlibatan masyarakat. Selain itu ada aspek politik dalam pembangunan inklusif. Ini terkait dengan prioritas politik dalam melaksanakan program pembangunan. Oleh karena itu strategi pembangunan pedesaan diharapkan dapat berdasar pada aspek potensial yang dimiliki oleh desa (Amanda 2015).

Penelitian ini bertujuan untuk mengidentifikasi potensi-potensi pada bidang pertanian, peternakan, pariwisata, serta perdagangan dan ekonomi yang dimiliki oleh 
desa guna meningkatkan kesejahteraan masyarakat desa. Dalam penelitian ini kami menggali lebih jauh potensi pedesaan dengan melihat kepada aspek potensi sektor ekonomi (pertanian dan pariwisata), peran dan keterlibatan masyarakat desa, serta rencana pengembangan desa atau visi dari pemimipin desa di Kecamatan Cilongok.

\section{TINJAUAN PUSTAKA DAN PERUMUSAN HIPOTESIS Paradigma Perencanaan Pembangunan}

Todaro dan Smith (2012) berpendapat pembangunan yang direncanakan sebagai surest and direct route to economic growth. Pada beberapa negara perencanaan dilaksanakan secara top down, yaitu semua perencanaan pembangunan ekonomi dibebankan kepada pemerintah pusat. Peran pemerintah dalam hal ini adalah mempersiapkan program pembangunan ekonomi nasional atau roadmap yang sesuai dengan kondisi dan karateristik negaranya. Dengan sistem terpusat, pembangunan ekonomi lebih terkendali hanya saja banyak kebijakan yang kurang sesuai dengan apa yang dibutuhkan oleh masyarakat atau daerah.

Ada juga yang berpendapat bahwa konsep perencanaan pembangunan suatu negara harus berorientasi pada prinsip keadilan atau equity. Konsep keadilan menurut pandangan ini adalah dengan lebih mendengarkan aspirasi masyarakat. Sehingga diharapkan dengan didengarnya aspirasi masyarkat dapat menghilangkan rasa ketidakadilan atas pelakasanaan kebijakan pemerintah karena kebijakan pembangunan sudah selaras dengan kebutuhan dan sumberdaya yang dimiliki (Al-Zawahreh and AlMadi 2012, Hatfield et al. 2012).

Konsep equity nampaknya sejalan dengan model otonomi daerah dimana masyarakat (dalam hal ini pemerintah daerah) berhak mengelola sumberdaya daerahnya masing-masing. Selain itu konsep ini juga sejalan dengan teori perencanaan aplikatif, yaitu guna mewujudkan pembangunan suatu wilayah perlu sebuah peta rencana ( $p l a n$ and guideline) yang kemudian akan menjadi dasar pelaksanaan program guna mengatasi permasalahan dalam masyarakat (Prihatin et al. 2019).

Melalui otonomi daerah, Indonesia mulai bergeser dalam menerapkan perencanaan pembangunan, yaitu menjadi bottom up. Tujuannya agar semua aspirasi masyarakat daerah dapat terserap oleh pemerintah pusat dan pelaksanaan pembangunan sejalan dengan potensi yang dimiliki oleh daerah tersebut karena masyarakatlah yang paham dengan jelas tentang segala potensi yang dimiliki (Kim et al. 2014). Tidak hanya paradigma pembangunan saat ini mengalami pergeseran, dari top-down menjadi bottom-up, namun juga pembangunan menekankan pada aspek pemberdayaan masyarakat atau people centered development, pembangunan berbasis sumber daya lokal (resource-based development) dan pembangunan kelembagaan (Suswanto et al. 2013).

\section{Desa dan Potensi Ekonomi Desa}

Pemerintahan desa merupakan lembaga perpanjangan pemerintah pusat yang dapat memiliki peran strategis dalam pengaturan masyarakat desa atau kelurahan untuk percepatan keberhasilan pembangunan nasional (Rafsanzani et al. 2010). Menurut Syahza dan Suarman (2013), pembangunan pedesaan harus dilakukan dengan pendekatan yang sesuai dengan sifat dan cirinya.

Pembangunan pedesaan harus mengikuti empat upaya besar, satu sama lain saling berkaitan dan merupakan strategi pokok pembangunan pedesaan. Pertama, memberdayakan ekonomi masyarakat desa (Ulumiyah 2013, Zulkarnaen 2016). Dalam 
upaya ini diperlukan masukan modal dan bimbingan-bimbingan pemanfaatan teknologi dan pemasaran untuk memampukan dan memandirikan masyarakat desa; Kedua, meningkatkan kualitas sumberdaya manusia pedesaan agar memiliki dasar yang memadai untuk meningkatkan dan memperkuat produktivitas dan daya saing.

Ketiga, pembangunan prasarana di pedesaan. Untuk daerah pedesaan prasarana perhubungan merupakan kebutuhan yang mutlak, karena prasarana perhubungan akan memacu ketertinggalan masyarakat pedesaan; dan keempat, membangun kelembagaan pedesaan baik yang bersifat formal maupun nonformal. Kelembagaan yang dibutuhkan oleh pedesaan adalah terciptanya pelayanan yang baik terutama untuk memacu perekonomian pedesaan seperti lembaga keuangan (Syahza and Suarman 2013, Ulumiyah 2013, Abidin 2015). Penyelenggaraan pemerintahan dibidang pembangunan pada dasarnya adalah kunci keberhasilan pengembangan potensi ekonomi lokal untuk menguatkan daya saing daerah (Husna, 2013, Sidik 2015, Soleh 2017).

Pemetaan potensi lokal merupakan suatu kegiatan yang dilakukan untuk menemukan dan mengenali potensi sosial ekonomi dan budaya masyarakat lokal atau disebut juga sebagai kegiatan orientasi sosial (Moerad et al. 2016, dan Kartika, 2018). Kegiatan ini merupakan bagian dari proses sosialisasi awal, dilakukan setelah dan atau bersamaan dengan kegiatan Kunjungan informal ke kelompok-kelompok strategis di tingkat desa/kelurahan.

Kondisi sosial budaya dan sosial ekonomi yang perlu ditemukenali mencakup beberapa kondisi sebagai berikut: nilai-nilai apakah yang dianut oleh masyarakat secara dominan yang mampu menggerakkan masyarakat; kekuatan-kekuatan sosial apakah yang mampu mendatangkan perubahan-perubahan sehingga masyarakat dapat berubah dari dalam diri mereka sendiri; seperti apa karakter dan karakteristik masyarakat, khususnya dalam menyikapi intervensi sosial; seperti apakah pola informasi komunikasi yang terjadi di tengah masyarakat baik penyebaran informasi maupun dalam kerangka pembelajaran; Media-media seperti apakah dan sumber belajar apakah yang digunakan dan diyakini masyarakat sebagai sarana informasi dan pembelajaran; Kekuatan-kekuatan sosial yang dominan di dalam kerangka perubahan social; Faktor-faktor lingkungan apakah yang berpengaruh terhadap sikap dan perilaku masyarakat (Moerad et al. 2016).

\section{Prospek Pengembangan Ekonomi Desa}

Pengembangan basis ekonomi di pedesaan sudah semenjak lama dijalankan oleh pemerintah melalui berbagai program. Namun upaya itu belum membuahkan hasil yang memuaskan sebagaimana diinginkan bersama. Salah satu faktor yang paling dominan adalah intervensi pemerintah terlalu besar, akibatnya justru menghambat daya kreativitas dan inovasi masyarakat desa dalam mengelola dan menjalankan mesin ekonomi di pedesaan. Sistem dan mekanisme kelembagaan ekonomi di pedesaan tidak berjalan efektif dan berimplikasi pada ketergantungan terhadap bantuan pemerintah sehingga mematikan semangat kemandirian.

Idealnya, kegiatan-kegiatan ekonomi masyarakat desa dilaksanakan dalam bentuk kelembagaan atau badan usaha yang dikelola secaran professional (Abidin 2015, Zainudin 2016), namun tetap bersandar pada potensi asli desa. Hal ini dapat menjadikan usaha masyarakat lebih produktif dan efektif. (Attar et al. 2013, Sidik 2015, Zulkarnaen 2016). 
Keuangan desa merupakan hierarki struktur keuangan sentral dari pemerintahan di atasnya. Kabupaten, propinsi, dan pemerintah pusat mempunyai andil besar dalam pengalokasian sumber keuangan desa (Widagdo et al. 2016). Desa sebagai pemerintahan yang memahami dengan jelas potensi baik sumberdaya alam maupun sumber daya manusia diharapkan bisa mandiri secara ekonomi. Menurut Abdurokhman (2014) pengembangan potensi desa dapat mendorong kemandirian masyarakat desa/kelurahan melalui pengembangan potensi unggulan dan penguatan kelembagaan serta pemberdayaan masyarakat.

Secara khusus, tujuan pengembangan potensi desa ialah meningkatkan peran aktif masyarakat dalam pengambilan keputusan pembangunan secara terbuka, demokratis dan bertanggung jawab; mengembangkan kemampuan usaha dan peluang berusaha demi peningkatan pendapatan dan kesejahteraan rumah tangga miskin; dan mendorong terwujudnya keterpaduan peran dan kemitraan antar Dinas/ Instansi Provinsi dan Kabupaten/Kota maupun stakeholders lainnya sebagai pelaku dan fasilitator program Potensi desa teridentifikasi melalui karakteristik fisik (tanah, air, iklim, keadaan geografis dan SDM) dan nonfisik (semangat gotong-royong, Lembaga desa, Lembaga pendidikan, Lembaga Kesehatan, Lembaga Ekonomi, Aparatur dan pamong desa) yang secara eksisting dimiliki oleh desa (Abdurokhman 2014)..

\section{METODE PENELITIAN}

Penelitian ini merupakan penelitian deskriptif dengan menggunakan analisis data sekunder dan data primer untuk mengidentifikasi potensi-potensi ekonomi di Kecamatan Cilongok. Data sekunder diperoleh dari Badan Pusat Statistik (BPS) Kabupaten Banyumas. Data primer diperoleh melalui wawancara dengan dua puluh kepala desa yang berada di wilayah administratif Kecamatan Cilongok. Wawancara dilakukan dengan menanyakan potensi sektor unggulan di tiap desa. Penelitian ini membagi ke dalam empat potensi sektor desa yang ditanyakan kepada tiap kepala desa, yaitu potensi di sektor pertanian, peternakan, sektor pariwisata, dan sektor usaha Mikro Kecil dan Menengah (UMKM).

Analisis data sekunder dalam penelitian ini untuk melihat potensi sumber daya alam seperti lahan pertanian dan perkebunan yang ada di Kecamatan Cilongok. Analisis ini dilakukan dengan mendeskripsikan data sekunder mengenai luas lahan dan hasil sumber daya alam yang mampu dihasilkan. Selain itu penelitian ini juga melihat pada potensi pengembangan ternak yang ada di Kecamatan Cilongok.

Untuk mengetahui ada tidaknya pemusatan ternak di Kecamatan Cilongok, penelitian ini menggunakan metode Location Quitient (LQ) (Amiruddin and Taufik 2015). Perhitungan LQ pada ternak akan dibagi menjadi dua, yaitu untuk ternak ruminansia (sapi perah, sapi potong, kerbau, dan kambing) dan untuk ternak nonruminansia (ayam ras, itik, dan ayam kampung).

$$
L Q_{\text {ruminansia }}=\frac{\frac{X_{i j}}{\sum_{i=1}^{4} X_{i j}}}{\sum_{i=1}^{20} X_{i j}}
$$




$$
L Q_{\text {non-ruminansia }}=\frac{\frac{X_{i j}}{\sum_{i=1}^{3} X_{i j}}}{\sum_{i=1}^{20} X_{i j}}
$$

Jika nilai $L Q \geq 1$ untuk jenis ternak tertentu maka desa tersebut menjadi basis komoditasnya. Sementara jika LQ $<1$ maka desa itu bukan basis ternak tersebut. Dengan perhitungan ini diharapkan potensi peternakan di Kecamatan Cilongok dapat teridentifikasi.

Identifikasi potensi sektor pariwisata dilakukan dengan wawancara tiap kepala desa di Kecamatan Cilongok mengenai ada tidaknya potensi pengembangan pariwisata di desanya. Dari hasil wawancara ini dapat diperoleh gambaran mengenai desa mana saja yang berpotensi untuk dikembangkan wisatanya dan desa mana yang belum memiliki potensi wisata.

Untuk melihat potensi dalam bidang usaha UMKM, penelitian ini memadukan data primer hasil wawancara dengan tiap kepala desa dan data sekunder. Data primer digunakan untuk menggali informasi keragaman usaha dan komoditas yang dihasilkan oleh UMKM di tiap desa. Data sekunder dgunakan sebagai identifikasi sebaran jumlah dan serapan tenaga kerja di Kecamatan Cilongok.

\section{HASIL DAN PEMBAHASAN}

\section{Potensi di Sektor Pertanian}

Hasil dari wawancara dengan kepala desa, diperoleh data hasil produksi pertanian sebagaimana pada Tabel 1.

Tabel 1 Produksi Pertanian yang Dominan di Kecamatan Cilongok

\begin{tabular}{clcccc}
\hline \multirow{2}{*}{ No } & \multicolumn{1}{c}{ Desa } & \multicolumn{5}{c}{ Komoditas } \\
\cline { 3 - 6 } & & Padi & Holtikultura & Perikanan & Palawija \\
\hline 1 & Batuasem & $\sqrt{ }$ & $\sqrt{ }$ & $\sqrt{ }$ & - \\
2 & Kasegeran & $\sqrt{ }$ & - & - & $\sqrt{ }$ \\
3 & Jatisaba & $\sqrt{ }$ & - & - & $\sqrt{ }$ \\
4 & Panusupan & $\sqrt{ }$ & - & - & $\sqrt{ }$ \\
5 & Pejogol & - & - & - & $\sqrt{ }$ \\
6 & Pageraji & $\sqrt{ }$ & - & - & $\sqrt{ }$ \\
7 & Sudirama & $\sqrt{ }$ & - & - & $\sqrt{ }$ \\
8 & Cilongok & $\sqrt{ }$ & - & - & $\sqrt{ }$ \\
9 & Cipete & $\sqrt{ }$ & $\sqrt{ }$ & - & $\sqrt{ }$ \\
10 & Cikidang & $\sqrt{ }$ & - & - & $\sqrt{ }$ \\
11 & Pernasidi & - & - & - & $\sqrt{ }$ \\
12 & Langgongsari & $\sqrt{ }$ & $\sqrt{ }$ & - & $\sqrt{ }$ \\
13 & Rancamaya & $\sqrt{ }$ & - & - & $\sqrt{ }$ \\
14 & Panembangan & $\sqrt{ }$ & - & - & - \\
15 & Karanglo & $\sqrt{ }$ & - & - & $\sqrt{ }$ \\
16 & Kalisari & $\sqrt{ }$ & $\sqrt{ }$ & - & \\
17 & Karangtengah & $\sqrt{ }$ & - & - & \\
18 & Sambirata & $\sqrt{ }$ & - & - &
\end{tabular}




\begin{tabular}{cccccc}
\hline \multirow{2}{*}{ No } & \multirow{2}{*}{ Desa } & \multicolumn{4}{c}{ Komoditas } \\
\cline { 2 - 6 } & Padi & Holtikultura & Perikanan & Palawija \\
\hline 19 & Gununglurah & $\sqrt{ }$ & - & - & $\sqrt{ }$ \\
20 & Sokawera & $\sqrt{ }$ & - & $\mathbf{1}$ & $\mathbf{1 7}$ \\
\hline & Jumlah & $\mathbf{1 8}$ & $\mathbf{4}$ & -
\end{tabular}

Sumber: Hasil Wawancara

Hasil wawancara pada Tabel 1 menunjukkan bahwa 18 dari 20 Kepala Desa yang ada di Kecamatan Cilongok, menganggap daerahnya dominan memproduksi padi. Jika dilihat secara geografis, Kecamatan Cilongok adalah daerah agraris dengan penggunaan lahan sebanyak 1.967 hektar untuk persawahan. Data dari BPS menunjukkan bahwa penggunaan lahan untuk persawahan terdiri dari 45 persen adalah lahan sawah dengan menggunakan irigasi sederhana dan 33 persen adalah sawah dengan irigasi teknis dan semi teknis, serta 22 persen adalah sawah tadah hujan. Dari keadaan lahan sawah ini, pada tahun 2018 Kecamatan Cilongok memproduksi padi sebanyak 5,78 ton/ha. Nilai ini lebih rendah dari total produktivitas padi secara keseluruhan di Kabupaten Banyumas, yaitu 5,80 ton/ha.

Sementara itu, hasil wawancara dengan kepala desa pada Tabel 1 juga menunjukkan 17 dari 20 desa di Kecamatan Cilongok dominan dalam memproduksi palawija. Tanaman palawija yang dominan diproduksi diantaranya adalah ketela, ubi jalar, jagung, kacang-kacangan, dan kapulaga. Data dari BPS menunjukkan bahwa penggunaan lahan sebesar 3.000 hektar atau kurang lebih 29 persen dari luas wilayah Kecamatan Cilongok adalah untuk lahan perkebunan. Dari 3.000 hektar ini 2.400 hektar adalah perkebunan rakyat dan 600 hektar adalah tegal. Hasil produksi dari perkebunan palawija ini cukup besar, sebagaimana ditunjukkan pada Tabel 2.

Tabel 2 Produktivitas Palawija di Kecamatan Cilongok dibandingkan dengan Rata-Rata Produktivitas Palawija di Kabupaten Banyumas

\begin{tabular}{clcc}
\hline No & \multicolumn{1}{c}{ Komoditas } & $\begin{array}{c}\text { Kecamatan } \\
\text { Cilongok }\end{array}$ & $\begin{array}{c}\text { Kabupaten } \\
\text { Banyumas }\end{array}$ \\
\hline 1 & Ketela Pohon (Ton/Ha) & 26,91 & 20,79 \\
2 & Ubi Jalar (Ton/Ha) & 22,18 & 16,41 \\
3 & Kacang Tanah (Ton/Ha) & 2,52 & 2,33 \\
4 & Pisang (Kw/Pohon) & 1,77 & 0,67 \\
5 & Durian (Kw/Pohon) & 2,12 & 1,17 \\
6 & Kelapa Deres (Ton/Ha) & 12,67 & 10,64 \\
7 & Pala (Ton/Ha) & 0,32 & 0,30 \\
\hline
\end{tabular}

Sumber: Dinas Komunikasi dan Informasi Kabupaten Banyumas, 2019

Tabel 2 menunjukkan bahwa terdapat tujuh komoditas palawija dari Kecamatan Cilongok yang produktivitasnya di atas rata-rata produktivitas kabupaten. Ini merupakan salah satu potensi komoditas yang dapat dimanfaatkan oleh masyarakat di Kecamatan Cilongok selain potensi tanaman pangan padi. Dengan masa panen relatif lebih singkat dibandingkan dengan padi, komoditas sektor perkebunan bisa menjadi pilihan bagi Kecamatan Cilongok.

\section{Potensi di Sektor Peternakan}

Untuk sektor peternakan, hasil perhitungan LQ untuk ternak ruminansia (sapi perah, sapi biasa, kerbau, dan kambing) dapat dilihat pada Tabel 3. 
Tabel 3 Hasil Perhitungan LQ untuk Ternak Ruminansia di Kecamatan Cilongok Tahun

\begin{tabular}{clcccc}
\multicolumn{7}{c}{2018} \\
\hline No & \multicolumn{1}{c}{ Desa } & Sapi Perah & Sapi Biasa & Kerbau & Kambing \\
\hline 1 & Batuasem & 0.00 & 3.34 & 0.31 & 1.01 \\
2 & Kasegeran & 0.00 & 2.73 & 0.12 & 1.04 \\
3 & Jatisaba & 0.00 & 6.28 & 0.35 & 0.96 \\
4 & Panusupan & 0.00 & 7.44 & 0.11 & 0.96 \\
5 & Pejogol & 0.00 & 4.69 & 0.08 & 1.00 \\
6 & Pageraji & 0.00 & 4.07 & 0.00 & 1.02 \\
7 & Sudirama & 0.00 & 3.91 & 0.11 & 1.02 \\
8 & Cilongok & 0.00 & 6.47 & 0.11 & 0.97 \\
9 & Cipete & 0.00 & 4.89 & 0.00 & 1.01 \\
10 & Cikidang & 0.00 & 3.28 & 0.00 & 1.03 \\
11 & Pernasidi & 0.00 & 2.94 & 0.00 & 1.04 \\
12 & Langgongsari & 0.00 & 3.73 & 0.22 & 1.01 \\
13 & Rancamaya & 0.00 & 1.47 & 0.16 & 1.05 \\
14 & Panembangan & 0.00 & 10.04 & 0.35 & 0.90 \\
15 & Karanglo & 0.00 & 2.04 & 0.27 & 1.04 \\
16 & Kalisari & 0.00 & 4.68 & 0.29 & 0.99 \\
17 & Karangtengah & 34.27 & 2.54 & 0.12 & 0.96 \\
18 & Sambirata & 28.58 & 3.38 & 0.20 & 0.96 \\
19 & Gununglurah & 27.12 & 2.36 & 0.21 & 0.98 \\
20 & Sokawera & 0.00 & 1.98 & 0.05 & 1.05 \\
\hline
\end{tabular}

Sumber: Hasil Analisis. 2019.

Nilai LQ untuk ternak ruminansia besar (sapi perah, sapi biasa, dan kerbau) biasanya lebih besar jika dibandingkan dengan ternak ruminansia kecil (domba dan kambing) (Daud 2009). Tabel 3 menunjukkan bahwa untuk produksi ternak ruminansia, sumber daya Kecamatan Cilongok masih memberi dukungan terhadap ternak ruminansia. Hal ini ditandai dengan meratanya populasi ternak di tiap wilayah. Populasi ternak sapi perah terkonsentrasi di tiga desa yaitu Desa Karangtengah, Sambirata, dan Gununglurah. Untuk sapi biasa, pemusatan populasi hampir di setiap wilayah. Ini ditunjukkan dengan nilai LQ lebih dari satu. Sedangkan untuk kerbau tidak terdapat konsentrasi populasi kerbau di desa dalam wilayah Kecamatan Cilongok. Untuk ternak kambing, terdapat pemusatan populasi kambing di 12 desa.

Sementara hasil perhitungan LQ untuk ternak non-ruminansia (ayam ras, itik, dan ayam kampung) dapat dilihat pada Tabel 4. Tabel tersebut menunjukkan hasil perhitungan LQ untuk ternak non-ruminansia atau unggas. Populasi ayam ras, terpusat di 9 desa dengan desa paling tinggi populasinya adalah Desa Langgonsari. Sementara untuk itik terjadi pemusatan populasi di 10 desa, dan untuk populasi ayam kampong terjadi pemusatan di 8 desa.

Tabel 4 Hasil Perhitungan LQ untuk Ternak Non-Ruminansia di Kecamatan Cilongok Tahun 2018

\begin{tabular}{clccc}
\hline No & Desa & Ayam Ras & Itik & Ayam Kampung \\
\hline 1 & Batuasem & 0.00 & 1.67 & 0.87 \\
2 & Kasegeran & 0.00 & 1.49 & 0.91 \\
3 & Jatisaba & 0.00 & 0.83 & 1.07
\end{tabular}




\begin{tabular}{clccc}
\hline No & \multicolumn{1}{c}{ Desa } & Ayam Ras & Itik & Ayam Kampung \\
\hline 4 & Panusupan & 0.00 & 1.12 & 1.00 \\
5 & Pejogol & 1.31 & 1.37 & 0.90 \\
6 & Pageraji & 2.44 & 1.91 & 0.74 \\
7 & Sudirama & 0.00 & 0.90 & 1.05 \\
8 & Cilongok & 3.25 & 1.27 & 0.86 \\
9 & Cipete & 1.81 & 0.82 & 1.02 \\
10 & Cikidang & 2.44 & 0.95 & 0.97 \\
11 & Pernasidi & 1.27 & 1.32 & 0.91 \\
12 & Langgongsari & 3.53 & 1.38 & 0.83 \\
13 & Rancamaya & 2.54 & 0.83 & 0.99 \\
14 & Panembangan & 1.77 & 1.04 & 0.97 \\
15 & Karanglo & 0.00 & 1.28 & 0.96 \\
16 & Kalisari & 0.00 & 1.43 & 0.93 \\
17 & Karangtengah & 0.86 & 0.11 & 1.22 \\
18 & Sambirata & 0.00 & 0.76 & 1.09 \\
19 & Gununglurah & 0.00 & 0.99 & 1.03 \\
20 & Sokawera & 0.00 & 1.16 & 0.99 \\
\hline
\end{tabular}

Sumber: Hasil Analisis. 2019

Hasil indentifikasi komoditas sektor peternakan menunjukkan bahwa sebaran komoditas ternak di Kecamatan Cilongok sudah cukup merata, terutama untuk komoditas Sapi dan Kambing. Sementara untuk ternak non-ruminensia sudah tersebar secara merata di Kecamatan Cilongok, khususnya untuk komoditas ayam kampung.

\section{Potensi Sektor Wisata}

Hasil dari wawancara terkait ada tidaknya potensi sektor wisata di Kecamatan Cilongok dapat dilihat pada Tabel 5. Dari hasil wawancara tersebut, 11 desa menurut tiap kepala desanya memiliki potensi wisata, sementara 9 desa lainnya tidak. Meski sebagian besar desa memilki potensi wisata, namun menurut data resmi dari BPS, desa yang memilki ketersediaan objek wisata hanya Desa Karangtengah. Desa ini memilki objek wisata yang menjadi salah satu destinasi wisatawan untuk berkunjung ke Kabupaten Banyumas, yaitu curug cipendok. Selain itu Desa Karangtengah memilki fasilitas pendukung seperti tersedianya tempat penginapa hotel dan losmen, sementara desa lainnya tidak.

Dengan demikian, jika melihat pada hasil wawancara di Tabel 5, masih terdapat beberapa desa yang belum tersentuh. Misalnya di desa Panusupan dan Sokawera terdapat potensi wisata alam seperti goa lawa dan pemandangan alam daerah perbukitan. Sementara di desa Cilongok dan Cikidang terdapat potensi wisata air seperti river tubing dan wisata waduk. Ada juga desa yang memanfaatkan potensi perkebunannya dengan menjadikan agrowisata seperti di Desa Langgongsari.

Tabel 5 Potensi Wisata di Kecamatan Cilongok

\begin{tabular}{ccccc}
\hline \multirow{2}{*}{ No } & \multirow{2}{*}{ Desa } & \multicolumn{2}{c}{ Potensi Wisata } \\
\cline { 3 - 4 } & & Ada & Tidak \\
\hline 1 & Batuasem & & & $\sqrt{ }$
\end{tabular}




\begin{tabular}{clcc}
\hline \multirow{2}{*}{ No } & \multicolumn{1}{c}{ Desa } & \multicolumn{2}{c}{ Potensi Wisata } \\
\cline { 3 - 4 } & & Ada & Tidak \\
\hline 2 & Kasegeran & & $\sqrt{ }$ \\
3 & Jatisaba & $\sqrt{ }$ & \\
4 & Panusupan & & $\sqrt{ }$ \\
5 & Pejogol & & $\sqrt{ }$ \\
6 & Pageraji & & \\
7 & Sudirama & $\sqrt{ }$ \\
8 & Cilongok & $\sqrt{ }$ & \\
9 & Cipete & $\sqrt{ }$ & \\
10 & Cikidang & $\sqrt{ }$ & \\
11 & Pernasidi & $\sqrt{ }$ \\
12 & Langgongsari & & \\
13 & Rancamaya & $\sqrt{ }$ \\
14 & Panembangan & & $\sqrt{ }$ \\
15 & Karanglo & & \\
16 & Kalisari & $\sqrt{ }$ & \\
17 & Karangtengah & $\sqrt{ }$ & \\
18 & Sambirata & $\sqrt{ }$ \\
19 & Gununglurah & $\sqrt{ }$ \\
20 & Sokawera & $\mathbf{1 1}$ & $\mathbf{9}$ \\
\hline
\end{tabular}

Sumber: Hasil Wawancara

\section{Potensi di Sektor Usaha Mikro Kecil dan Menengah (UMKM)}

Jumlah industri kecil dan rumah tangga di Kecamatan Cilongok dapat dilihat pada Tabel 6. Industri di Kecamatan Cilongok didominasi oleh industri rumah tangga. Ada sebanyak 7.365 indsutri rumah tangga dengan penyerapan tenaga kerja sebanyak 14.739. Konsentrasi industri rumah tangga berada pada dua desa yaitu Desa Panusupan dan Desa Pageraji.

Komoditas industri rumah tangga di Desa Panusupan dapat dilihat pada Tabel 7, yaitu industri jasa pengerajin batu bata dan pengolahan bahan makanan. Industri pengolahan makanan di desa Panusupan sebagian besar adalah berbahan dasar pisang dan singkong. Industri pengolahan bahan makanan sejalan dengan potensi sumber daya lokal yang dimiliki oleh Kecamatan Cilongok, karena produksi bahan dasar sinkong dan pisang berada di atas rata-rata produktivitas Kabupaten Banyumas.

Sementara itu untuk Desa Pageraji, indsutri yang dominan adalah industri gula kelapa dan gula semut. Komoditas gula semut ini merupakan salah satu komoditas unggulan Kabupaten Banyumas. Jika dilihat pada tabel 7, komoditas gula semut memang banyak diproduksi oleh sebagian besar desa di Kecamatan Cilongok.

Sebagian besar industri gula semut yang ada di Kecamatan Cilongok juga melibatkan berbagai macam pihak. Misalnya di Desa Batuanten, Sudimara, dan Cipete sudah melakukan kerjasama dengan PT. Coco Sugar sebagai perusahaan yang bersedia untuk menjadi pengepul hasil gula semut.

Temuan lain dalam industri rumah tangga ini adalah di Desa Kalisari. Desa ini merupakan sentra penghasil tahu di Kecamatan Cilongok. Hasil dari wawancara dengan Kepala Desa di Desa Kalisari, bahwasannya jumlah pengrajin tahu yang berproduksi ada sebanyak 248 pengrajin. Industri tahu di desa kalisari memang sudah lama beroperasi, namun demikian karena bahan bakunya tidak diproduksi di dalam negeri 
maka produksi tahu kalisari seringkali terkendala dengan tingginya harga impor kedelai.

Tabel 6 Potensi Usaha di Kecamatan Cilongok

\begin{tabular}{clrrrr}
\hline \multirow{2}{*}{ No } & \multicolumn{2}{c}{ Desa } & \multicolumn{2}{c}{ Industri Kecil } & \multicolumn{2}{c}{ Industri Rumah Tangga } \\
\cline { 3 - 6 } & & Jumlah & $\begin{array}{c}\text { Tenaga } \\
\text { Kerja }\end{array}$ & Jumlah & $\begin{array}{c}\text { Tenaga } \\
\text { Kerja }\end{array}$ \\
\hline 1 & Batuasem & 2 & 13 & 555 & 1.110 \\
2 & Kasegeran & 9 & 54 & 188 & 385 \\
3 & Jatisaba & 11 & 66 & 305 & 610 \\
4 & Panusupan & 5 & 30 & 1.010 & 2.020 \\
5 & Pejogol & 5 & 30 & 132 & 264 \\
6 & Pageraji & 12 & 72 & 1.184 & 2.368 \\
7 & Sudirama & 13 & 78 & 281 & 562 \\
8 & Cilongok & 15 & 102 & 705 & 1.410 \\
9 & Cipete & 9 & 55 & 326 & 652 \\
10 & Cikidang & 5 & 27 & 85 & 170 \\
11 & Pernasidi & 5 & 33 & 292 & 584 \\
12 & Langgongsari & 6 & 36 & 307 & 614 \\
13 & Rancamaya & 5 & 34 & 133 & 266 \\
14 & Panembangan & 5 & 35 & 182 & 364 \\
15 & Karanglo & 4 & 24 & 113 & 226 \\
16 & Kalisari & 15 & 82 & 326 & 652 \\
17 & Karangtengah & 3 & 18 & 275 & 550 \\
18 & Sambirata & - & - & 306 & 612 \\
19 & Gununglurah & 3 & 18 & 362 & 724 \\
20 & Sokawera & 2 & 11 & 298 & 596 \\
\hline \multicolumn{7}{l}{ Jumlah } & $\mathbf{1 3 4}$ & $\mathbf{8 1 8}$ & $\mathbf{7 . 3 6 5}$ & $\mathbf{1 4 . 7 3 9}$ \\
\hline
\end{tabular}

Sumber: Hasil Wawancara

Tabel 7 Komoditas Industri di Kecamatan Cilongok

\begin{tabular}{|c|c|c|c|c|}
\hline $\begin{array}{l}\text { Gula Kelapa } \\
\text { dan Gula } \\
\text { Semut }\end{array}$ & $\begin{array}{l}\text { Pengrajin } \\
\text { Kayu, } \\
\text { Bambu/Anya } \\
\text { man }\end{array}$ & $\begin{array}{l}\text { Makanan } \\
\text { Olahan }\end{array}$ & Tahu & Kopi \\
\hline $\begin{array}{l}\text { 1. Batuanten } \\
\text { 2. Kasegaran } \\
\text { 3. Pageraji } \\
\text { 4. Sudimara } \\
\text { 5. Cilongok } \\
\text { 6. Cipete } \\
\text { 7. Langgongs } \\
\text { ari } \\
\text { 8. Rancamaya } \\
\text { 9. Panembang } \\
\text { an } \\
\text { 10. Sambir } \\
\text { ata } \\
\text { 11. Sokawe } \\
\text { ra }\end{array}$ & $\begin{array}{l}\text { 1. Panusupan } \\
\text { 2. Pejogol } \\
\text { 3. Cipete } \\
\text { 4. Langgongsari } \\
\text { 5. Panembangan } \\
\text { 6. Karanglo } \\
\text { 7. Karangtengah }\end{array}$ & $\begin{array}{l}\text { 1. Jatisaba } \\
\text { 2. Panusupan } \\
\text { 3. Pejogol } \\
\text { 4. Cilongok } \\
\text { 5. Cikidang } \\
\text { 6. Pernasidi } \\
\text { 7. Panembang } \\
\text { an } \\
\text { 8. Karanglo } \\
\text { 9. Kalisari } \\
\text { 10. Karangt } \\
\text { engah } \\
\text { 11. Sambira } \\
\text { ta Gunungl } \\
\text { 12. Gun }\end{array}$ & $\begin{array}{l}\text { 1. Panembang } \\
\text { an } \\
\text { 2. Kalisari }\end{array}$ & $\begin{array}{l}\text { 1. Gununglur } \\
\text { ah }\end{array}$ \\
\hline
\end{tabular}


urah

13. Sokawer

a

Sumber: Hasil Wawancara

\section{KESIMPULAN}

Dari hasil analisis potensi ekonomi desa yang ada di Kecamatan Ciongok untuk sektor pertanian dan perkebunan, komoditas perkebunan lebih dominan dibandingkan dengan komoditas dari sektor pertanian. Untuk sektor peternakan, sumber daya kecamatan cilongok masih memberikan dukungan terhadap populasi ternak baik ruminansia dan non-ruminansia. Ternak yang sebaran populasinya paling merata adalah ternak unggas, sementara untuk ternak sapi perah populasinya masih berada di desa tertentu. Untuk sektor pariwisata, Kecamatan Cilongok hanya memilki satu destinasi wisata di satu desa saja yang dikelola oleh pemerintah. Meski ada potensi daerah wiasata di desa-desa lainnya namun belum dikelola dengan serius. Terakhir terkait dengan industri kecil dan rumah tangga, untuk Kecamatan Cilongok sebagian besar didominasi oleh industri rumah tangga dengan komoditas produk yang dibuat adalah olahan bahan makanan berbahan lokal seperti pisang sngkong, dan ubi, serta industri rumah tangga penghasil gula kelapa dan tahu.

Implikasi penelitian ini dapat dibagi menjadi dua sudut pandang. Pertama dari pengambil kebijakan. Berdasar kesimpulan yang kami peroleh, sektor perkebunan memilki potensi yang lebih tinggi disbanding dengan sektor pertanian. Jika dibandingkan dengan komoditas tani, maka koomditas perkebunan memilki masa tunggu yang relative lebih singkat. Ini berdampak pada kesempatan panen hasil perkebunan bisa dinikmati lebih cepat. Pembuat kebijakan dapat lebih mendorong sektor perkebunan ini. Namun demikian, hal ini tidak serta merta mengabaikan sektor pertanian, ini lebih kepada peningkatan proporsi komoditas perkebunan terhadap komoditas pertanian.

Untuk sektor peternakan, sebaran ternak yang bervariasi terutama pada komoditas ternak unggas berpotensi untuk meningkatkan perdagangan ternak antar desa. Untuk komoditas ternak sapi perah karena terpusat, maka potensi perdagannya antar desa rendah. Sementara untuk sektor pariwisata, masih sedikitnya potensi wisata desa di Kecamatan Cilongok dapat berarti masih sedikitnya investasi dan sarana pendukung wisata yang ada di kecamatan ini. Pengambil kebijakan dapat memberikan insentif bagi desa untuk melakukan investasi pariwisata lalu mengajukan promosi kepada lembaga atau dinas terkait.

Untuk sektor usaha, dengan potensinya adalah dalam UMKM sektor pengolahan, maka implikasinya adalah pemberdayaan dan peningkatan nilai tambah komoditas UMKM. Sektor UMKM cukup nyata dalam menyerap tenaga kerja, sehingga bisa menjadi opsi kebijakan oleh pemerintah daerah. 
Kedua, pandangan teoritis. Implikasi penelitian ini adalah diharapkan dapat memberikan analisis dalam melakukan identifikasi potensi pedesaan untuk melaksanakan program perencanaan pembangunan desa. Dengan melakukan studi lapangan, interview kepada pengambil kebijakan sekaligus meminta pandangannya terhadap potensi ekonomi yang ada di desanya.

\section{DAFTAR PUSTAKA}

Abdurokhman, D., \& Pd, M. (2014). Pengembangan Potensi Desa. Widyaiswara pada Kantor Diklat Kabupaten Banyumas

Abidin, M. Z. (2015). Tinjauan atas pelaksanaan keuangan desa dalam mendukung kebijakan dana desa. Jurnal Ekonomi \& Kebijakan Publik, 6(1), 61-76

Al-Zawahreh, A., \& Al-Madi, F. (2012). The utility of equity theory in enhancing organizational effectiveness. European journal of economics, finance and administrative sciences, 46(3), 159-169.

Amanda, H. W. (2015). Strategi Pembangunan Desa Dalam Meningkatkan Oendapatan Asli Desa Melalui Badan Usaha Milik Desa (Bumdes): Studi Pada Badan Pengelola Air Minum (Bpam) Di Desa Ketapanrame Kecamatan Trawas Kabupaten Mojokerto. Publika.

Taufik, C., \& Amiruddin, K. (2015). Analisis Pertumbuhan Ekonomi dan Pengembangan sektor Potensial di Kota Makassar.

Attar, M., Hakim, L., \& Yanuwiadi, B. (2013). Analisis potensi dan arahan strategi kebijakan pengembangan desa ekowisata di Kecamatan Bumiaji-Kota Batu. Journal of Indonesian Tourism and Development Studies, 1(2), 68-78..

Badan Pusat Statistik Kabupaten Banyumas. (2019). Kecamatan Cilongok dalam Angka 2019. Banyumas.

Chambers, R. (1994). Paradigm shifts and the practice of participatory research and development. Brighton: IDS.

Daud, A. R. 2009). Ananlisis Potensi Wilayah Pengembangan Ternak Ruminansia di Kabupaten Purwakarta. Sosiohumaniora, 126-139.

Dinas Komunikasi dan Informasi Kabupaten Banyumas. (2019). Data dan Informasi Kabupaten Banyumas 2019. Banyumas.

Hatfield, E., Rapson, R. L., \& Bensman, L. (2012). Equity theory. The Encyclopedia of Peace Psychology.

Kartika, M. (2018). Pemetaan Ekonomi Kreatif Subsektor Kuliner di Kota Pontianak. Jurnal Ekonomi Bisnis dan Kewirausahaan, 7(1), 58-71..

Husna, N. (2013). Analisis Pengembangan Potensi Ekonomi Lokal Untuk Menguatkan Daya Saing Daerah Di Kabupaten Gresik. Jurnal Administrasi Publik, 1(1), 188-196.

Kasser, T., Cohn, S., Kanner, A. D., \& Ryan, R. M. (2007). Some costs of American corporate capitalism: A psychological exploration of value and goal conflicts. Psychological Inquiry, 18(1), 1-22.

Kim, Y. H., Sting, F. J., \& Loch, C. H. (2014). Top-down, bottom-up, or both? Toward an integrative perspective on operations strategy formation. Journal of Operations Management, 32(78), 462-474. 
Moerad, S. K., Susilowati, E., \& Windiani, W. (2016). Pemetaan Potensi dan Dampak Ekonomi Masyarakat di Kawasan Pertambangan Bukit Tumpang Pitu Banyuwangi. JURNAL SOSIAL HUMANIORA (JSH), 9(2), 114-138.

Pouw, N., \& Gupta, J. (2017). Inclusive Development: A Multi-disiplinary Approach. Sustainability Science, 104-108.

Prihatin, D., Daryanti, S., \& Pramadha, R. A. (2019). Aplikais Teori Perencanaan: Dari Konsep Ke Realita. Yogyakarta: Buana Grafika.

Rafsanzani, H., Bambang S., \& Suwondo. (2010). Kemitraan Lembaga Pemberdayaan Masyarakat Desa Dengan Kepala Desa Dalam Perencanaan Pembangunan Desa: Studi Kasus di Desa Sumber Ngepoh Kecamatan Lawang Kabupaten Malang. Jurnal Adminintrasi Publik, 1 (4).

Rivera, M., Knickel, K., Rios, I. D. Le, Ashkenazy, A., Pears, D. Q., Chebach, T., \& Sumane, S. (2017). Rethinking The Connections Between Agricultural Change and Rural Prosperity: A Discussion of Insights Derived from Case Studies in Seven Countries. Journal of Rural Studies, 1-10.

Sidik, F. (2015). Menggali potensi lokal mewujudkan kemandirian desa. JKAP (Jurnal Kebijakan dan Administrasi Publik), 19(2), 115-131.

Soleh, A. (2017). Strategi pengembangan potensi desa. Jurnal Sungkai, 5(1), 32-52.

Suswanto, B., Handoko, W., \& Sabiq, A. (2013). Model Community Development Sebagai Strategi Pemberdayaan Berbasis Kearifan Lokal. Jurnal Review Politik, 03, 298-312.

Syahza, A. and Suarman (2013). Strategi pengembangan daerah tertinggal dalam Upaya Percepatan Pembangunan Ekonomi Pedesaan. Jurnal Ekonomi Pembangunan, 14 (1), 126-139.

Todaro, M. P. and Smith, S. C. (2012). Economics Development. $11^{\text {th }}$ Edition. Boston: Pearson Education Inc.

Ulumiyah, I. (2013). Peran pemerintah desa dalam memberdayakan masyarakat desa (studi pada Desa Sumberpasir Kecamatan Pakis Kabupaten Malang). Jurnal Administrasi Publik, 1(5), 890-899.

Widagdo, A. K., Widodo, A., \& Ismail, M. (2016). Sistem Akuntansi Pengelolaan Dana Desa. Jurnal Ekonomi dan Bisnis, 19(2), 323-340.

Zainudin, A. (2016). Model Kelembagaan Pemerintahan Desa. JIP (Jurnal IImu Pemerintahan): Kajian Ilmu Pemerintahan dan Politik Daerah, 1(2), 338-351.

Zulkarnaen, R. M. (2016). Pengembanga Potensi Ekonomi Desa Melalui Badan Usaha Milik Desa (BUMDES) Pondok Salam Kabupaten Purwakarta. Jurnal Aplikasi Ipteks untuk Masyarakat, 5 (1), 1-4. 